\title{
Szkice
}

\section{Wielkie deportacje środkowoeuropejskie z lat 1939-1950 w perspelktywie aksjologicznej. Wyzwanie dla literatury ${ }^{1}$}

\author{
Stefan Chwin
}

TEKSTY DRUGIE 2016, NR 3, S.11-41

DOI: $10.18318 / \mathrm{td} .2016 .3 .2$

C

hcę tutaj przedstawić wstępną propozycję systematyzacji perspektyw aksjologicznych, jakie występują w polskich i niemieckich narracjach deportacyjnych z drugiej połowy XX wieku i początku XXI wieku, a także rozpoznać, jakiego rodzaju aksjologiczne wyzwania dla literatury stanowił (i stanowi nadal) temat masowych przesiedleń i wypędzeń, podejmowany przez wielu pisarzy oraz kronikarzy, świadków i uczestników tych zdarzeń, których relacje wciąż ukazują się w Polsce i w Niemczech. Problematyka, jaką podejmuję, łączy się z ogólniejszym pytaniem, wkraczającym na teren filozofii historii i filozofii egzystencji, a mianowicie z kwestią, jak (wedle jakich kryteriów) oceniać masowe deportacje, do których doszło w Europie Środkowo-Wschodniej w połowie XX wieku. Mimo że pewne strategie oceny utrwaliły się w świadomości społecznej (a także w świadomości

1 Niniejszy referat jest zmienioną i rozszerzoną wersją referatu przedstawionego na międzynarodowej konferencji Umsiedlung, Vertreibung, Wiedergewinnung? Postkoloniale Perspektiven auf deutsche und polnische Literatur uber den ezwungenen Bevolkerungstransfer der Jahre 1944 bis 1950, Universitat Passau, 6 marca 2015.
Stefan Chwin - prof dr hab., historyk literatury, krytyk, pisarz. Pracuje w Katedrze Historii Literatury Instytutu Filologil Polskiej Uniwersytetu Gdańskiego. Ostatnio opublikował: Samobójstwo jako doświadczenie wyobraźni (2010), Samobójstwo $i_{\text {grzech istnienia }}$ (2013), Miłosz: interpretacje iświadectwa (2012), Miłosz. Gdańsk i okolice (2013) " Ein Deutsches Tagebuch" (2015). Kontakt: fposch@ug.edu.p 
badaczy) i uchodzą w dość powszechnej opinii za obowiązujące każdego, kto na temat deportacji i wypędzeń chce mówić i pisać, a nawet uznawane są do tego stopnia za oczywiste, że wyjście poza ich horyzont bywa przyjmowane protestami i gwałtownym oburzeniem jako naruszenie moralno-narodowego tabu, literatura wciąż kwestię tę stawia jako otwartą, czasem swoimi propozycjami aksjologicznymi wchodząc w otwarty konflikt z czytelnikami (i badaczami), przywiązanymi do określonych schematów myślenia i wartościowania, które nadal kierują naszą oceną przymusowych przemieszczeń ludności w powojennej Europie.

Dodam też, że - co ma pewne znaczenie - jestem nie tylko historykiem literatury, który z badawczym zaciekawieniem czyta i analizuje teksty o wypędzeniach, lecz także jednym ze „sprawców” samego tematu, polskim pisarzem, który jako syn wypędzonych Polaków dorastał w Gdańsku, w mieszkaniu po wypędzonych Niemcach i sporo o wypędzeniach napisał ${ }^{2}$, wiele rozmyślając nad tym, jak - z jakiej aksjologicznej perspektywy - prowadzić opowieść o tego rodzaju doświadczeniach historycznych.

\section{Aksjologia Nemmersdorfu}

W wielu narracjach - zarówno dawnych, jak i współczesnych - dominuje aksjologia Nemmersdorfu³. Akcentuje ona przede wszystkim niewinność (niemieckich, polskich) ofiar i horroryzuje sowieckie (polskie, czeskie) „bestie”,

2 Zob. np. S. Chwin Das Geheimnis der Vertreibung. Ein polnischer Schrifsteller uber Heimatverlust und die Logik der "ethnischen Sauberung", "Die Welt" 21.08.1999 ("Die Literarische Welt" 1999 $\mathrm{nr}$ 34, S. 2, 9); S. Chwin The Mystery of the "Good Evil" " Lituanus. Lithuanian Quarterly of Arts and Sciences" Spring 2006 Volume 52, $\mathrm{nr}$ 1, s. 5-16.

3 Narracja tego rodzaju rysuje obrazy wypędzeń i deportacji na podstawie modelu a bsolutnego, niczym racjonalnie nieumotywowanego okrucieństwa wobec niewinnych, odnoszącego się do wydarzeń z 21 października 1944 roku, kiedy to Armia Czerwona, wkraczając na terytorium Prus Wschodnich, dokonała masakry kilkudziesięciu mieszkańców przygranicznej niemieckiej miejscowości Nemmersdorf, co wywołało wielomilionową falę niemieckich ucieczek na zachód. „Przy pierwszej zagrodzie na lewo od drogi stał drabiniasty wóz. Do niego przybite za ręce w pozycji ukrzyżowanej były cztery nagie kobiety. [...] Na drzwiach [stodoły] przybito dwie nagie kobiety w pozycji ukrzyżowanej. W mieszkaniu znaleźliśmy w sumie siedemdziesiąt dwie kobiety i dzieci [...] Wśród zabitych były też niemowlęta, którym roztrzaskano czaszki twardym przedmiotem. W jednym z mieszkań znaleźliśmy siedzącą na kanapie starą, całkowicie ślepą, 84-letnią kobietę [...] Miała przepołowioną głowę, rozpłataną - prawdopodobnie toporem lub łopatą - od ciemienia aż po szyję". Cyt. za: M. Podlasek W skórze Niemca - ten kraj już nie był ich ojczyzng, w: Przeprosić za wypędzenie? O wysiedleniu Niemców po ll woinie światowei, red. K. Bachmann, Znak, Kraków 1997, s. 78. 
zmuszające ludność aktami trudno wyobrażalnego okrucieństwa do opuszczenia tradycyjnych miejsc osiedlenia, a po zakończeniu wojny dopuszczające się wobec Niemców brutalnych aktów przemocy fizycznej i administracyjnej ${ }^{4}$.

Tego, co naprawdę wydarzyło się w Nemmersdorfie, pewnie nie dowiemy się już nigdy. Część historyków kwestionuje liczbę ofiar i fakt krzyżowania przez Rosjan kobiet i dzieci. Mimo tych wątpliwości mit Nemmersdorfu stał się jednym z najsilniejszych mitów powojennej świadomości niemieckiej ${ }^{5}$, współtworząc sugestywny topos wypędzeń ze wschodu jako niemieckiej Golgoty. „Na wszystkich ustach była jedna tylko nazwa, miejsca grozy - Nemmersdorf" - czytamy w jednej z relacji ${ }^{6}$.

W aksjologicznym polu Nemmersdorfu dominują obrazy sowieckiego okrucieństwa złączonego z przemocą seksualną wobec niewinnych. Ten splot pojawia się w wielu relacjach, nabierając równocześnie znaczeń sprzecznych,

4 Jak silna i trwała jest to aksjologia, dowodzi np. powieść Reinharda lirgla Niedopetnieni (przeł. R. Wojnakowski, Borussia, Olsztyn 2009) o powojennych wypędzeniach Niemców z Sudetów, gdzie. co prawda, mowa jest o niemieckiej przemocy uderzającej w narody słowiańskie, ale szczegółowa narracja unaoczniająca jest zarezerwona dla obrazów przemocy wymierzonej w zwykłych, niewinnych Niemców. U Jirgla w obrazach tych dominuje przede wszystkim daleko posunięta szczegółowość: białe opaski na rękawach, 8 kg bagażu na osobę „ "upychanie" ludzi w bydlęcych wagonach, 30 minut na spakowanie, tłum Czechów krzyczący i klaszczący z uciechy na widok uciekającej ludności niemieckiej, drwiny, szyderstwa, kopanie i bicie. Zbrodnie Czechów na Niemcach są tutaj opisywane techniką monstrualnych zbliżeń filmowych. „Ludzie na boisku, jeńcy i strażnicy, zbili się w kłębowisko [...] pręty \& pięści uniosły się ponad tą masą niczym odnóża powalonego na grzbiet olbrzymiego owada, poruszającego się w szarobiałym wrześniowym powietrzu w poszukiwaniu oparcia - co jakiś czas jedna z postaci waliła się na trawę, jakby od tłumu odpadał ciężki ballast" (s. 16). lednym z detali eksponowanych w maksymalnym zbliżeniu jest krew płynąca z ucha Niemki po wyrwaniu kolczyka. Natomiast zbrodnie niemieckie są w tej powieści przedstawiane w narracji ogólnikowej, nieunaoczniającej, oczyszczonej z równie drastycznych szczegółów, "oddalającej" opisywaną scenę od widza-czytelnika: "Podobno SS tuż-przed-końcem-wojny rozstrzelało [...]" (s. 15). Horroryzacji deportujących "bestii” służyły też demoniczne metafory opisujące narzędzia sprawców wypędzeń. Np. w powieści Zbigniewa Żakiewicza pociąg z Polakami wypędzonymi z polskich Kresów Wschodnich został przedstawiony na podobieństwo monstrualnego gada z metalowych zwojów (tegoż Willio, w głębokości morza, Krajowa Agencja Wydawnicza, Kraków 1992, s. 168). Innego rodzaju horroryzacja pociągu deportacyjnego pojawiała się w powieści Stanisława Srokowskiego Repatrianci (Czytelnik, Warszawa 1988), gdzie wagony z deportowanymi jechały przez deszcz krwi (s. 368).

5 O "policy on horror scenes" w filmach propagandowych III Rzeszy zob. R.C. Raack Nazi Propaganda and the Horrors of War, "Historical Journal of Film, Radio and Television" 1986 Vol. 6, Issue 2, s. 189-195.

6 Ch. Graf von Krockow Czas kobiet. Wspomnienia z Pomorza 1944-1947. Wedtug relacii Libussy Fritz-Krockow, przeł. I. Burszta-Kubiak, CDN, Warszawa 1990, s. 36. Dalej w tekście Czas kobiet i numer strony. 
które wymagają uważnej analizy. W polu podstawowym okrucieństwo łączone jest z kobiecą nagością i toposem ukrzyżowania, umieszczając akty przemocy w przestrzeni bluźnierstwa religijnego. W niektórych narracjach topos Nemmersdorfu, łączący tortury seksualne z obraźliwą parodią ukrzyżowanej niewinności, znajduje swój ironiczny rewers w obrazach kobiet, które - inaczej niż kobiety straumatyzowane aktami przemocy seksualnej - czują się dowartościowane przez to, że jako ofiary skupiają na sobie uwagę niemieckiej społeczności, a nawet wyrażają - co jest opatrywane przez narratorów ironicznym komentarzem - paradoksalną dumę z „wyczynu”, jakim było zniesienie zbiorowego gwałtu . Jeśli w macierzystym, propagandowym wzorze zhańbienie kobiet zawierało w sobie silny element eugenicznego upokorzenia (gwalt odczuwany jako przemoc zadana przez niższą rasę $e^{8}$ ), tutaj silnie akcentuje się zderzenie niemieckiej niewinności z niespożytą energią seksualną Rosjan, podkreślając wielką ilość gwałtów przypadających na jednego rosyjskiego żołnierza. Poprzez materię opowieści prześwituje mityczny obraz Germanii gwałconej przez syberyjskiego „niedźwiedzia” o niewyczerpalnej potencji seksualnej. Towarzyszą temu częste wzmianki o tym, że Rosjanie właściwie gwałcili wszystko, bez względu na urodę i wiek, nie wyłączając zwierząt, a nawet - jak w książce Jürgena Thorwalda - trupów Niemek ${ }^{9}$

7 Libussa von Krockow pisała, że u zgwałconych przez Rosjan Niemek "miesza się [...] z przestrachem duma z wyczynu" (Ch. Graf von Krockow Czas kobiet..., s. 55). Zwracała też uwagę na kpiarskie eufemizowanie gwałtów zbiorowych ("musiała przyznać 13 razy") oraz kpiny niemieckich mężczyzn ze starych Niemek zgwałconych przez "Azjatów". W relacji Hannah von Harnack Ostatnie tygodnie wojny w Poczdamie pojawiało się zdanie: „Jakaś dziewczyna opowiada ze łzami w oczach o tym, jak została zgwałcona, ale ponieważ wszyscy w związku z tym koncentrują na niej uwagę, zdaje się nawet dość zadowolona ze swoich przygód" (M. Weber Kobiety wypędzone. Opowieść o zemście zwycięzców, przeł. G. Kowalski, Replika, Zakrzewo 2008 , s. 356, dalej: Kobiety wypędzone i numer strony). Zupełnie inaczej sprawę postawy kobiet wobec wojennych gwałtów przedstawia w swojej książce Bożena Karwowska, utrwalając stereotyp bariery wieloletniego milczenia, blokującej rzekomo możliwość szybkiego i pełnego wypowiedzenia przez ofiary doświadczenia gwałtu zbiorowego. Zob. Druga płeć na wygnaniu. Doświadczenie migracyine w opowieściach powojennych pisarek polskich, Universitas, Kraków 2013, S. 141-143.

8 Libussa von Krockow podkreślała szok pierwszego, upokarzającego spotkania z żołnierzami sowieckimi: "zwycięzców wyobrażamy sobie inaczej” (Ch. Graf von Krockow Czas kobiet..., s. 37), akcentując ich fizyczną marność i materialną nędzę (obdarci, obszarpani, bez prawdziwych butów).

9 I. Thorwald Wielka Ucieczka, przeł. A. Band, J. Sczaniecka, Wydawnictwo Literackie, Kraków 1998, s. 57: „W Szydłowie, na południowy zachód od Opola, widziałem raz dwudziestu czerwonoarmistów, stojących przed zwłokami wielokrotnie zgwałconej, mającej z całą pewnością 
Na tym tle charakterystyczne są obrazy Polaków w niemieckich narracjach, znacznie bardziej ich lekceważące jako pomagierów Rosjan ${ }^{10}$ - wyzbytych prawdziwie azjatyckiego rozmachu i biologicznej mocy. O Rosjanach mówi się „bestie”, o Polakach „polsko-żydowskie hieny”"1. Jeśli Polaków po klęsce Niemiec na terenach poniemieckich $w$ niemieckich narracjach przedstawiano jako prymitywnych ludzi zemsty i rabunku, sowiecka przemoc seksualna, której obrazy pojawiają się w narracjach deportacyjnych, dyfungowała swoim monstrualnym rozmachem poza granice tego degradującego schematu.

Mimo brutalnej akcji kolonizacyjnej na wschodzie „sowiet” jawił się w wyobraźni niemieckiej jako niewolnik o niespożytej sile witalnej, w swojej istocie nigdy nieskolonizowany do końca. Jeśli w narracjach deportacyjnych narratorzy i narratorki chętnie szydzili z polnische Wirtschaft, widząc w niej dowód na niepełnowartościowość Polaków - rasy „przejściowej” między wschodem a zachodem, a więc dużo mniej wyrazistej niż Rosjanie - w obrazie Rosji oprócz administracyjnego rabowania dóbr poniemieckich przez Armię Czerwoną uwagę narratorów przykuwały setki razy powtarzane z hipnotyczną szczegółowością opisy niemieckich domów, w których Rosjanie niszczyli absolutnie wszystko, bez żadnej racjonalnie wytłumaczalnej potrzeby. W obrazie Rosji krzyżowały się sprzeczne ujęcia: niewyobrażalna żądza zniszczenia i równocześnie rozrzutne rozsiewanie życia, poczucie poniżenia, a zarazem nieprzyjemne zdziwienie, że Rosjanie jako marna genetycznie rasa potrafią równocześnie być niezwyciężoną potęgą ${ }^{12}$, ale złodziejski, szczurzy „szaber” przypisywano przede wszystkim Polakom ${ }^{13}$.

więcej niż sześć dziesiąt lat starej kobiety. Wyli i wrzeszczeli, by zaspokoić swoje zwierzęce żądze na już pozbawionym życia ciele".

W Czasie kobiet pojawiało się ironiczno-pogardliwe określenie Polaków jako drugorzędnej "świty” Rosjan. Libussa von Krockow "mnogość gwałtów” rosyjskich, „zuchwałość i zwycięskie prawo pięści" Rosjan przedstawiała jako przykład przemocy, którą "można jeszcze zrozumieć”. Władzę Polaków charakteryzowała wyłącznie jako "coś zimnego, skrytego i przebiegłego, by nie powiedzieć podstępnego - i w tym sensie coś znacznie głębiej przejmującego grozą niż brutalna przemoc" Rosjan (s. 73). W jej ujęciu Polacy na terenach poniemieckich byli gorsi i bardziej przerażający niż żołnierze Armii Czerwonej.

11 Relacja Rity von Gaudecker (M. Weber Kobiety wypędzone..., s. 268).

W obrazach Rosjan stereotypy antysowieckie mieszały się z rasistowską azjatyzacją wroga. U Libussy von Krockow sowieci to nędzna biologicznie "wataha”, małe, "niesamowite postacie” o "szpotawych nogach" i „skośnych oczach" (Ch. Graf von Krockow Czas kobiet..., s. 37). 
Być zgwałconym przez Rosjanina znaczyło być zgwałconym przez mroczną siłę Azji, brudną, pierwotną, nieokrzesaną potęgę tellurycznych mocy rosyjskiej ziemi. Być poniżonym przez Polaka znaczyło być poniżonym przez niewolnika, który w genach nosi podległość. W wielu narracjach o wypędzeniach dochodziło do głosu przekonanie, że niemiecka kolonizacja Polski była skuteczna, twardo wyznaczając Polakom ich właściwy status. Upokorzenie przez polskiego urzędnika odczuwano jako bardziej dotkliwe niż administracyjną przemoc ze strony umundurowanych Rosjan, prawdziwych panów sytuacji ${ }^{14}$. Aksjologia Nemmersdorfu obsługiwała zatem dwa sprzeczne cele: umieszczała Rosjan "na dole” jako rasę biologicznie i cywilizacyjnie niższą, ale także „na górze” jako potęgę niewolników, którzy nigdy nie stali się prawdziwymi niewolnikami (znamienne były porównania niemieckich wypędzonych, uciekających przed Armią Czerwoną, do niedobitków armii napoleońskiej pokonanej pod Moskwą przez niezwyciężoną potęgę rosyjskiej zimy) $)^{15}$.

Rewersem tej aksjologii było odbieranie przez narratorów rosyjskiej przemocy seksualnej jako „kastracji” niemieckich mężczyzn. Nie przypadkiem Jürgen Thorwald zamieścił w swojej książce scenę, w której sowieccy „azjaci” po zgwałceniu kobiet niemieckich miażdżyli kamieniami jądra niemieckiego mężczyzny, który bronił gwałconej żony ${ }^{16}$. W narracjach kobiecych powracały obrazy całkowicie bezwolnych, słaniających się na nogach jeńców niemieckich, którym Rosjanie „odebrali” męskość, zmieniając ich w kołyszące się na zaśnieżonych drogach kolumny szarych cieni ${ }^{17}$.

Granicą tego rodzaju aksjologii było powszechne w narracjach deportacyjnych niedostrzeganie związku między furią rosyjskiej przemocy seksualnej

jącej” mieszanki ras ( $M$. Weber Kobiety wypędzone..., s. 102, 108, 179), "barbarzyństwa Hunów z azjatyckich stepów", ,ludzi pierwotnych", prymitywów, szczutych przez komunistyczną propagandę (J. Thorwald Wielka Ucieczka, s. 56).

14 Libussę von Krockow wyprowadzała z równowagi świadomość, że zajęcie terenów niemieckich przez Polaków to Generalna Gubernia à rebours: „Polacy jako panowie, Niemcy jako pachołki" (Ch. Graf von Krockow Czas kobiet..., s. 72).

15 M. Donhoff Nazwy, których już się nie wymienia, przeł. G. Supada, posł. L. Żyliński, „Borussia”, Olsztyn 2001, s. 28.

J. Thorwald Wielka ucieczka, s. 35.

17 W powieści Hugo Hartunga Gdy niebo zstapiło pod ziemię (przeł. D. Lesisz, Wydawnictwo Via Nova, Wrocław 2008) pochód uchodźców niemieckich był stylizowany na pochód widm. Język narracji akcentował sytuację wypędzonych jako „zaszczutych” ofiar (s. 59). 
i ideologią i praktyką niemieckiej akcji kolonizacyjnej na Wschodzie. Przemoc rosyjska mogła być odpowiedzią na okrucieństwo armii niemieckiej - takie wyjaśnienia dopuszczano - nie łączono jej jednak z praktyką kolonizowania Rosji wedle idei eugenicznej. Trudno znaleźć w narracjach o wypędzeniach choćby podejrzenie, że rosyjski żołnierz ak tami gwałtu rozładowywał swoje upokorzenie, jakim naznaczyła go niemiecka kolonizacja Wschodu, oparta na rasistowskim przekonaniu o prokreacyjnej niepełnowartościowości Słowian.

Przez narrację wiele razy prześwitywały nazistowskie klisze: obraz fizycznie spotworniałych „azjatów”, którzy nie wiedzą, co to łazienka i sedes, stosy saskiej porcelany przeobrażają w kaleczącą miazgę gnojówki, a rwą się do niemieckich kobiet ${ }^{18}$. Te somatyczne fantazmaty reaktywne (lęk przed brudnym dotknięciem sfery intymnej) odgrywały ważną rolę w deportacyjnych narracjach kobiecych. Ważne też było radykalne przeciwstawienie symboliki nocy i symboliki dnia, ściślej: nocnej przemocy seksualnej Rosjan (wdzierania się w ciemności do mieszkań, piwnic i stodół) i dziennego, słonecznego wizerunku rosyjskiego komendanta, mężczyzny w mundurze, który broni ludności niemieckiej przed niższą, chaotyczną, niezorganizowaną "zgrają" Czechów czy Polaków (np. napadających na pociąi z uchodźcami niemieckimi). Tak „sowiet” z Nemmersdorfu - brutalny, bluźnierczy, prymitywny zabójca sfeminizowanego niemieckiego „Jezusa” ukrzyżowanego w niemieckiej Golgocie na wrotach stodoły - przeistaczał się w opiekuna i wybawcę, władzę militarną, podobną w istocie do niemieckiej, a więc łatwiejszą do strawienia. W części narracji powracał obraz Niemców garnących się do umundurowanego Rosjanina ze strachu przed polską czy czeską przemocą 19 .

18 W oczach Libussy "sowieci" to "potomkowie Attyli albo Dżingis-Chana", "duże dzieci", ludzkie bestie wydające "dziki wrzask” (Ch. Graf von Krockow Czas kobiet..., 45). Znamienne, że w Czasie kobiet kolorystyczna percepcja zdarzeń utożsamiała Rosjan i Polaków z obrzydliwą barwą "ziemistobrązową" (ziemistobrązowy mundur sowieckiego żołnierza, s. 86). U Thorwalda Rosjanie to "szarobrązowi" (35). W relacji Rity von Gaudecker niszczycielska furia Rosjan była tak szaleńcza, że ostrzeliwali oni nawet przelatujące dzikie gęsi (M. Weber Kobiety wypędzone..., 230). "Przerażający Mongoł” "natychmiast niszczy telefon”, "kopie piec elektryczny”, "rozbija kolbą radio" (227). „Ubikacja iłazienka w bardzozłym stanie. Ostatni burgund wylany do wanny" (239). Dziewczęta napadane są przez "wstrętnych mężczyzn” (231).

W Czasie kobiet czytamy: „Tylko nieba wiedzą, jak długo jeszcze pozostaną nasi dobrzy Rosjanie i będą nas bronić" przed Polakami (s. 73). Hannah von Harnack oprócz informacji, że Rosjanie nie znali widelców i jedli palcami podkreślała szacunek "Rosjan dla nauki i jej przedstawicieli” oraz ich podziw dla bibliotek prywatnych (M. Weber Kobiety wypędzone.., s. 370). W relacji Asbeck Polacy na terenach poniemieckich uprawiali "niecne procedery" (140). Władza Polaków to władza „motłochu” (292). Nawet opisy polskiej fizjonomii miały charakter degradujący: polski ko- 
Tak właśnie aksjologia Nemmersdorfu pozwalała ujrzeć Rosję jako potęgę, która, łącząc w sobie głębokie sprzeczności - lęk i fascynację, przerażenie i przyciąganie - ma w sobie coś z mrocznego numinosum, tak jak doświadczenie numinosum opisywał Rudolf Otto ${ }^{20}$.

Aksjologia zbliżona do aksjologii Nemmersdorfu pojawiała się także w polskiej kulturze i to w wielu przypadkach jako aksjologia dominująca. Najradykalniejszym jej wcieleniem stała się powieść Stanisława Srokowskiego Repatrianci, chociaż dla wielu Polaków rzeź na Wołyniu z roku 1943, o której w tej książce mowa, już dużo wcześniej była polskim Nemmersdorfem. Bardzo silny w polskiej kulturze negatywny topos ukraińskiego „rezuna”, po wymyślnych torturach zabijającego niewinną polskość, siłą swojego fantazmatycznego oddziaływania potrafił przyćmić zbrodnie niemieckie (np. na Zamojszczyźnie) czy sowieckie (Katyń). U Srokowskiego pociąg z wygnańcami, deportowanymi z Wołynia i Polesia na tereny poniemieckie, jest symbolem ostatecznej traumy spotkania z irracjonalną przemocą absolutną, która przechodzi wszelkie wyobrażenia. Deportacja z Wołynia to ucieczka z piekła ${ }^{21}$. Podobnie jak w niemieckiej aksjologii Nemmersdorfu, Srokowski zupełnie pominął psychosocjologiczne przyczyny ukraińskich zbrodni. Polski Nemmersdorf - tak jak niemiecki - nie ma w jego powieści przeszłości, jest tylko niekończącą się teraźniejszością bólu, wiecznie przeżywanego przez wypędzonych. Tylko w jednym miejscu ktoś mówi u Srokowskiego, że zbrodnie

mendant więzienia miał twarz "czerwoną jak burak" i „ryczał” po polsku, domagając się wódki (Ch. Graf von Krockow Czas kobiet..., 78). Na poczcie rządzi "czerwona jak burak Polka" (M. Weber Kobiety wypędzone.., 256). Polacy „bardzo groźni i nieprzyjemni” (233) „ "straszne typy” (257) wyrzucające z domów całe rodziny niemieckie w dziesięć minut. "Polacy coraz bardziej się szarogęszą" (264), „żyją w brudzie i najczystszy dom w zdumiewająco krótkim czasie przekształcają w śmietnisko. Czują się dobrze tylko wtedy, gdy mogą bezmyślnie niszczyć i brudzić". Są brudniejsi od niemieckich zwierząt (305). "Obrzydliwcy” (272) „ "polskie łotry” (274) obrabowują Niemców w pociągu deportacyjnym. „Rosjanie okazują się raczej wybawieniem niż zagrożeniem. Podli Polacy ulegają im" (269). W jednej z opowieści występował nawet prawdziwie niemiecki pies, który "Podczas spacerów na smyczy unikał ludzi w rogatywkach na głowach" (71). Inaczej przedstawiani byli zwykle przez kronikarzy Polacy ze sfer inteligenckich i oficerowie. Wspominano także o przyjaznych zachowaniach niektórych Polaków, ale obrazy negatywne zdecydowanie dominują.

20 R. Otto Świętość: elementy irracjonalne w pojęciu bóstwa i ich stosunek do elementów racjonalnych, przeł. B. Kupis, Thesaurus Press, Wrocław 1993.

21 "Powrozy nam zakładano na ciała i ciągali nas tymi powrozami za końmi, na powrozach nas ciągali i na drutach kolczastych. [...] W nasze ciała wbijano pale i gwoździe, palono naszą skórę, ogień podkładano pod nasze ciała [...]. Na nasze szyje nakładano pętle. Za nogi nas wieszano, ręce nam przekręcano, skóra nam pękała" (Repatrianci, s. 262). 
ukraińskie na Wołyniu wyrosły z ukraińskiego cierpieni $\mathrm{a}^{22}$, trauma deportowanych Polaków jest jednak tak silna, że blokuje dochodzenie do prawdy o historycznej genezie zdarzeń, podobnie jak aksjologia Nemmersdorfu blokuje dochodzenie do prawdy o psychologicznych źródłach sowieckiej przemocy na terenach Prus Wschodnich zajmowanych przez Armię Czerwoną. Nikt nie rozważa tu przyczyn radykalnego okrucieństwa podporządkowanych, którzy radykalną brutalnością odreagowywali wielowiekową sytuację podporządkowania i upokorzenia, nikt też nie mówi o moźliwości pojednania. Aksjologia Nemmersdorfu - zarówno w niemieckiej, jak i w polskiej literaturze - wyklucza bowiem wszelką mediację między byłym kolonizatorem i zbuntowanym, oszalałym w swoim okrucieństwie subalternem, domagającym się wyrównania zadawnionych rachunków.

\section{Rozbrajanie aksjologii Nemmersdorfu w narracjach o wypędzeniach}

Kanoniczne ujęcia aksjologii Nemmersdorfu i jej późniejsze warianty, choć dominujące w Niemczech i Polsce, były w niemieckiej i polskiej literaturze rozmaicie podważane i burzone. Przykładowo w esejach Piotra Petera Lachmanna obraz „«wypędzenia» po polsku”, skonstruowany w stylu teatru absurdu Mrożka i „teatru niekonsekwencji” Różewicza, przekornym zachwytem dla polnische Wirtschaft oraz pochwałą niechlujstwa "polskich niewolników” uderzał w sam duchowy rdzeń klasycznych niemieckich narracji deportacyjnych: topos niewinnej Golgoty wypędzeñ ${ }^{23}$.W porównaniu z Seinsvertreibung - drwił Lachmann - wypędzenie Niemców z lat 1945-1950 było „małym piwem"24. Przeciwny temu, by z doświadczenia deportacyjnego robić centralny czy inicjalny punkt niemieckiej biografii indywidualnej i zbiorowej, niechętny wobec konserwatywnej aksjologii „zakorzenienia” na wschodzie, a także pełen dystansu wobec poetyki wzmacniania traumy wypędzeń, Lachmann przekornie wybierał konwencję opowieści groteskowo-ironicznej, a nawet komediowej. Klasycznym obrazom rabowania wypędzanych Niemców przez Polaków w pociągach deportacyjnych przeciwstawiał spiętrzone do absurdu,

22 W powieści Srokowskiego Repatrianci oprócz katalogu ukraińskich zbrodni pojawia się także znamienne przeciwstawienie Ukraińców jako „wściekłych psów” i Ukraińców jako "biednego narodu", który zabija Polaków z wielkiego cierpienia duszy، zatrutej urazami wzajemnych wojen, ale w narracji ten pierwszy obraz wroga zdecydowanie dominuje (132).

24 Tamże, s. 37. 
paradoksalne obrazy Niemców rabujących w 1945 roku pociąg z dobytkiem Polaków obrabowanych przez administrację niemiecką w Polsce, dodając do tego, że doświadczenie „seksu przyfrontowego" z czasu wypędzeń (a więc dziecięca wiedza o gwałtach zbiorowych) na zawsze - i na szczęście - wyrwało go z maskarady mieszczańskiego życia ${ }^{25}$.

Aksjologię Nemmersdorfu w jego esejach rozbijała też kluczowa metafora życia jako teatru, która zmieniała wypędzenia w rodzaj pedagogicznej gry, antymieszczański, przyspieszony kurs sztuki awangardowej i awangardowej scenografii - dawany przez ,zespół Gwałtu i Mordu Armii Czerwonej"26, co uderzało nie tylko w nostalgiczną mentalność ziomkostw czy represyjną mentalność neonazistów, ale także w samego... Zbigniewa Herberta, którego Lachmann uważał za poetę... nacjonalistyczno-plemiennego. Kluczem do historycznej prawdy o masowych deportacjach Niemców miała być gra językowa rodem z poezji i prozy Białoszewskiego, ironiczna narracja pełna cudzysłowów, która swoją graficzną nieprzejrzystością cały czas miała demaskować swój językowy status, broniąc narratora przed sentymentalną nostalgią deportacyjnych wspomnień.

Inaczej do sprawy podszedł Günter Grass ${ }^{\mathbf{2 7}}$, przekonany, że pod koniec XX wieku narracja spod znaku Nemmersdorfu zachowała w Niemczech zadziwiającą siłę, przy czym chodziło mu przede wszystkim o to, jak narracja ta funkcjonuje w kloace naszych czasów, czyli w Internecie. Mit „zbrodni na Gustloffie” - „ukrzyżowania” niemieckiej niewinności na pokładzie białego okrętu przez podstępnego, działającego w ciemnościach nocy sowieckiego subalterna ze Wschodu - który reanimowała internetowa prawica neonazistowska, zawierał w sobie - jak to Grass przedstawiał w powieści Idac rakiem - trujące połączenie autentycznego współczucia i szacunku dla niemieckich ofiar morskiej katastrofy z agresywną wolą rewanżu i zemsty.

Sposobem na rozbrojenie aksjologii Nemmersdorfu stała się racjonalistyczna narracja śledcza, zgodna z przekonaniem Grassa, że każda ideologia panicznie boi się szczegółów. Pedantycznie zgromadzone w powieści tysiące detali zdarzenia traumatycznego rozbijały od środka spójną ideologiczną wizję barbarzyńskiego „ukrzyżowania” wypędzonych, dowodząc punkt

\footnotetext{
25 Tamże, s. 64.

26 Tamże, s. 65.

27 G. Grass Idq̨ rakiem, przeł. S. Błaut, Polnord - Wydawnictwo Oskar, Gdańsk 2002.
} 
po punkcie, że „Gustloff” wcale nie był niewinną ofiarą, tylko uzbrojonym okrętem Kriegsmarine z żołnierzami i nazistami na pokładzie, którzy zresztą wcale nie popisali się w akcji ratunkowej (np. mężczyźni chętnie ratowali się kosztem kobiet), a drobiazgowy katalog zaniedbań i nieudolności kapitanów "Gustloffa" i załogi wskazywał, że nostalgiczna heroizacja ofiar, dominująca w narracjach prawicowych, jest zwykłym nadużyciem.

Szczególną rolę u Grassa odgrywała sprawa krzywdy kobiet niemieckich, kluczowa dla aksjologii Nemmersdorfu. Ideologicznym obrazom nagiej kobiecości „ukrzyżowanej” przez bestialskich Mongołów na wrotach stodoły we wschodniopruskiej wiosce Grass przeciwstawił desakralizujący obraz wojennej rzeźni w ładowniach trafionego sowiecką torpedą okrętu: ciała niemieckich dziewcząt $\mathrm{z}$ wojskowej służby pomocniczej rozsiekane na strzępy potłuczonymi kafelkami z basenu kąpielowego. Odsłaniał też prawdziwe tabu wszelkich narracji ideologicznych: zapachowy wymiar katastrofy. Barwą deportacyjnej tragedii „Gustloffa” w jego powieści był fetor zapchanych klozetów, smród niemytych ciał, rzeźnicza cielesność ran, co z jednej strony rozbijało wizję ideologiczną ${ }^{28}, z$ drugiej było językiem autentycznego współczucia dla fizycznego cierpienia ofiar, ginących na tonącym okręcie.

Aby zburzyć filozofię, która z wypędzeń robiła kamień węgielny niemieckiej tożsamości powojennej, inicjalny punkt zbiorowej i indywidualnej biografii, a narrację o niemieckim losie organizowała jako ciąg, historii o potwornościach" ${ }^{29}$, Grass drwił w swojej powieści z niemieckiej matki, która miała prawdziwego bzika na punkcie katastrofy „Gustloffa”, nieustannie powracając do wojennego zdarzenia z bolesną rozkoszą i jeszcze na dodatek zaszczepiając - ponad głowami liberalno-demokratycznych rodziców - tę bolesną rozkosz deportacyjnej samoudręki swojemu wnukowi, młodemu neonaziście ${ }^{30}$.

Celem Grassa było - jak pisał - "spłukanie" prawicowo-ideologicznych nawarstwień z narracji o wypędzeniach, osiągnięcie zatem obiektywnego stanu "la tylko relacjonuję" zgodnie z brutalną maksymą: historia to „zapchany klozet. Spłukujemy i spłukujemy a gówno mimo to wypływa" (s. 110).

Napisany z centrolewicowej perspektywy Im Krebsgang Grassa ukazał się w lutym 2002 roku. O miejscu narracji Grassa na tle niemieckiej „polityki pamięci" zob. R. Schulze The Politics of Memory: Flight et Expulsion of German populations after the Second World War an German Collective Memory, "National Identities" 2006 Vol. 8, Issue 4, s. 367-382. 


\section{Aksjologia bilansu biograficznego w narracjach deportacyjnych}

Aksjologia Nemmersdorfu projektowała narrację skupioną na chwili doznawania jednostkowej i zbiorowej krzywdy, na plan pierwszy wysuwając przekroczenie wszelkich granic przez żądnych zemsty niewolników. Służyła utrwalaniu traumy brutalnego wtargnięcia „barbarzyńskiego Wschodu” na cywilizowane tereny Niemiec, blokowała więc refleksję nad tym, co w życiu wypędzonych nastąpiło dużo później - po latach czy dziesięcioleciach od momentu wypędzeń. Jej rdzeniem było zatrzymanie czasu: nakaz nieustannego powracania do chwili, w której Niemcom zadano ból, podkreślanie ciągłości traumy, jaka na całe życie naznaczyła wypędzonych, a nawet przedstawianie procesu dziedziczenia traumy przez synów i wnuków ${ }^{31}$.

Współgrało z tym częste odwoływanie się do pojęcia naturalnego porządku świata, rozbitego przez brutalne wtargnięcie ze wschodu, przede wszystkim zaś poczucie naturalności prawa do posiadania niewolników². Sprawą wartą zbadania jest to, jakimi słowami w niemieckich narracjach deportacyjnych określano tzw. robotników przymusowych ze wschodu. Zwykle w miejsce tego określenia wprowadzano familiaryzmy i eufemizmy maskujące fakt niewolniczego podporządkowania. „Polska służąca” doktora Schneidera ${ }^{33}$, „rosyjska służąca" ${ }^{34}$, „nasi Polacy”, ,nasi pracownicy z innej

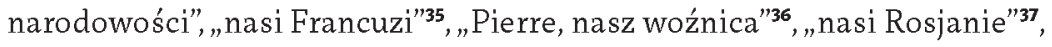

31 Rainer Schulze wskazuje na następujące książki mówiące o dziedziczeniu traumy przez trzecie pokolenie: I. Bernig Niemandszeit (DVA, München 2002), R. Jirgl Die Unvollendeten (Carl Hanser Verlag GmbH \& Co. KG, München 2003), T. Dückers Himmelskörper (Heavenly Bodies, Berlin 2003), O. Muller Schlesisches Wetter (Berlin Verlag, Berlin 2003), M. Zellner Die Reise nach Samosch (Ars Vivendi, Cadolzburg 2003).

Wśród "sytuacji archetypowych" narracji deportacyjnych powtarzało się przeciwstawianie idyllicznego stanu sprzed wypędzeń i brutalnego wyrwania z korzeniami ze stanu uznawanego za naturalny, zob. Wypędzeni ze wschodu, red. H.-J. Bomelburg, R. Stossinger, R. Traba, przeł. J. Górny i in., Borussia, Olsztyn 2001.

M. Weber Kobiety wypędzone..., s. 351.

34 Tamże, s. 374 .

35 Ch. Graf von Krockow Czas kobiet..., s. 10. „Praca zawsze pozostaje pracą, również wtedy, gdy przy zbieraniu kartofli do niemieckich kobiet i dzieci przyłączają się Francuzi i Ukrainki [...]"s. 18. Zdanie to sugerowało niemal dobrowo lną chęć przyłączenia się robotników przymusowych do niewolniczej pracy w majątku niemieckim na Pomorzu.

36 Ch. Grafvon Krockow Czaskobiet..., s. 34 .

37 M. Weber Kobiety wypędzone..., s. 141. 
"mój Rosjanin"38 „Wasyl rozpalił ogień w pralni" ${ }^{39}$. „Kazałam moim Rosjanom usuwać śnieg" - mówiła w jednej z relacji Inge Asbeck ${ }^{40}$.W narracjach o wypędzeniach Niemców z Sudetów wyczuwało się też protestancką niechęć do słowiańskiego katolicyzmu, przy czym niemieccy chrześcijanie bez najmniejszego trudu godzili swoją wiarę w Ewangelię z faktem posiadania robotników przymusowych ze wschodu. $Z$ dysgustem przyjmowano postawę niewolników, którzy po wyzwoleniu zaczynają wobec swoich panów zachowywać się samodzielnie, a nawet posuwają się do rewanżu za upokorzenia, jakich doznali podczas przymusowej służby. Chętnie natomiast pokazywano pracowników przymusowych, którzy tak wdrożyli się w swoją rolę, że swoich panów nie opuszczają nawet w trudnej sytuacji po wkroczeniu Rosjan, jak dobrzy, wierni niewolnicy murzyńscy, którzy po zniesieniu niewolnictwa na amerykańskim Południu nie chcieli porzucić właściciela plantacji.

W Czasie kobiet wchodziło też w grę podporządkowanie klasowe. Wywłaszczona przez Rosjan dziedziczka z niemiłym zdziwieniem dostrzegała nienawiść ubogiej Niemki, która nie kryła rozdrażnienia, kiedy nadal musiała służyć swej pani. Odwrócenie ról między panami i niewolnikami czy też ich zrównanie, które następowało podczas wypędzeń, było powodem silnej frustracji narratorek i narratorów, którzy - tak rysuje się główny wymiar czasowy wielu narracji - dzielili czas swojej biografii na czas naturalnego, zhierarchizowanego świata „sprzed" wypędzeń i czas niezgodnego z naturą świata zaburzonych hierarchii „po" wypędzeniach.

Narracja zgodna z aksjologią Nemmersdrofu przedstawiała deportacje jako doświadczenie niemal wyłącznie niszczące, uznając wypędzenie za najważniejszy, centralny punkt życia jednostki, zawłaszczający (czy zatruwający) całą biografię, na co Grass odpowiadał w swojej powieści, demaskując szczególną - jak uważał - nekrofilię wypędzonych, której sugestywnym obrazem miała być postać niemieckiej matki, przez całe życie żywiącej się trupimi jadami katastrofy „Gustloffa”.

Zupełnie inaczej stawiała sprawę aksjologia bilansu biograficznego. Ujmowała ona wypędzenie jako jeden z wielu epizodów biografii indywidualnej, którego sens aktualny relatywizowały późniejsze doświadczenia jednostki. Narracja zbliżała się wtedy do struktury powieści rozwojowej, a w przypadku

38 Tamże, s. 166.
39 Tamże, s. 150.
40 Tamże, s. 140. 
Czasu kobiet do powieści emancypacyjnej, w której wypędzenie - choćby najbardziej bolesne - jawiło się jako próba i szansa. W relacji Libussy von Krockow opowieść o wypędzeniu stawała się w istocie narracyjnym protestem przeciwko ojcu, który reprezentuje porządek patriarchalny. Tak ukierunkowaną opowieść deportacyjną rozdzierała zatem sprzeczność. Z jednej strony dochodziła do głosu silna nostalgia za naturalnym porządkiem sprzed wypędzeń, z drugiej właśnie zburzenie prusko-pomorskiego ładu, odczuwanego jako naturalny, przez dziką - i niższą - przemoc ze wschodu, daje bohaterce szansę na wydostanie się z krępującej ją, narzucanej przez niemieckich mężczyzn, tradycyjnej roli kobiety niemieckiej, co narratorka przedstawiała w finale swojej opowieści jako swój bolesny, ale jednak sukces.

Także w polskiej literaturze pojawiał się podobny typ narracji, przede wszystkim w deportacyjnych opowieściach o losach kobiet (np. W domu niewoli Beaty Obertyńskiej ${ }^{41}$ ). W narracji Obertyńskiej wrażliwa, życiowo niezaradna polska inteligentka nie załamuje się pod wpływem brutalnej deportacji na wschód, tylko przeciwnie: otwiera się na nowe doświadczenie, traktując wypędzenie jako paradoksalną szansę dla literatury. W jej ujęciu deportacja przy wszystkich jej dolegliwościach - to szansa na terenowe studia psychosocjologiczne, których wyniki pragnie utrwalić na wrażliwej błonie pamięci, ale także - podobnie jak u Libussy - to „czyściec”, który pozwala duszę oczyścić z inteligencko-szlacheckich złudzeń. W bilansie biograficznym, który stanowi strukturalną podstawę narracji, życie narratorki rozpada się na czas niepełnej wiedzy „przed" wypędzeniem i - dużo bardziej wartościowy w sensie twórczo-intelektualnym - czas bolesnego wtajemniczenia „po" wypędzeniu ${ }^{42}$.

Równie niekonwencjonalną aksjologię bilansu biograficznego w narracjach o wypędzeniach przynosił dyptyk powieściowy Haliny Auderskiej Ptasi gościniec i Babie lato ${ }^{43}$, gdzie autorka, prowadząc skomplikowaną grę z cenzurą, starała się podważyć czy choćby wycieniować jednoznaczny, optymistyczny

41 B. Obertyńska (M. Rudzka) W domu niewoli, posł. A. Szostkiewicz, Czytelnik, Warszawa 2005.

42 Innego rodzaju rachunek biograficzny pojawiał się u lózefa Czapskiego, który wskazywał, że deportacje części jeńców ze Starobielska do kopalń Workuty prawdopodobnieocaliły ich przed śmiercią w masakrze katyńskiej (Na nieludzkiejziemi, Znak, Kraków 2011, s. 27). Ta strategia porównań relatywizujących występowała u Czapskiego często. Nawet wywózka w karetce więziennej z obozu, kończąca się śmiercią, mogła ocalić przed śmiercią jeszcze gorszą (s. 36).

43 H. Auderska Ptasi gościniec, Książka i Wiedza, Warszawa 1976; Babie lato, Książka i Wiedza, Warszawa 1976. 
obraz deportacji na ziemie poniemieckie polskich wygnańców „od Lenino do Berlina", forsowany przez propagandę PRL, co zresztą udało jej się tylko do pewnego stopnia. Logika bilansu biograficznego, kierująca budową powieściowej fabuły, podważała tutaj nie tylko oficjalne, zgodne z polityką historyczną PZPR, ujęcia masowych deportacji Polaków na wschód po roku 1939, a potem masowych przesiedleń ze wschodu na ziemie poniemieckie w roku 1945, ale także kwestionowała emigracyjno-opozycyjną narrację o syberyjskiej męce Polaków, która przedstawiała wywózkę na wschód niemal wyłącznie jako druzgoczące doświadczenie polskiej Golgoty.

Logika pozytywnego bilansu biograficznego wypędzeń, zgodna w dużym stopniu z linią propagandy okresu PRL ${ }^{44}$, doszła natomiast silnie do głosu np. we wspomnieniach Wojciecha Jaruzelskiego, który jako chłopiec - zresztą potomek zesłańców syberyjskich - został w 1941 roku wagonem bydlęcym deportowany przez Kirow, Swierdłowsk, Omsk i Nowosybirsk do Bijska w Kraju Ałtajskim, gdzie stracił ojca, ale także - jak opowiadał - znalazł swego rodzaju rodzinę zastępczą w środowisku żołnierzy Berlinga, Polaków wypędzonych, tak jak on, w głąb Rosji, którzy pomogli mu zrobić karierę wojskową najpierw podczas wojny, a potem w socjalistycznej Polsce. Sam Jaruzelski - który po wojnie brał udział w masowych wysiedleniach Ukraińców z okolic Hrubieszowa do radzieckiej Ukrainy, co też ma swoją wymowę - nigdy nie skarżył się na własne wypędzenie, traktując je jako wyznaczony mu przez okoliczności historyczne czas na przeistoczenie się katolickiego wychowanka gimnazjum księży marianów w ideowego komunistę i zarazem - jak to podkreślał - polskiego patriotę 45 .

W powieści Auderskiej, pomyślanej jako epicka powieść rozwojowa, aksjologia bilansu biograficznego komplikowała oba te jednoznaczne ujęcia. Jej bohater, przed wypędzeniem człowiek o nieokreślonej tożsamości narodowej,,,tutejszy" mieszkaniec Polesia, nieidentyfikujący się z Polską, stawał się Polakiem właśnie dzięki... deportacjom na wschód. Bilans jego powieściowej biografii wcale nie prowadził jednak - wbrew gładkim wzorcom propagandy - do wniosków jednoznacznych. Przeciwnie: w finale powieści były

Takie ujęcie rysowało się np. w popularnej powieści lanusza Przymanowskiego Czterejpancerni i pies (1964-1970), polskiego pisarza, który w latach 40. jako więzień gułagu, deportowany w głąb Rosji, pracował w sowieckich kamieniołomach, potem wstąpił do armii Berlinga i razem z nią wrócił do Warszawy, gdzie zrobił wojskową i partyjną karierę we władzach PRL.

45 Generał. Woiciech Jaruzelski w rozmowie z lanem Osieckim, Prószyński i Spółka, Warszawa 2014, S. 31-43. 
powstaniec warszawski, Polak z poczuciem klęski, prześladowany w czasach stalinizmu i Polak-zesłaniec z armii Berlinga, polski osadnik na ziemiach poniemieckich, siadali na brzegu Odry, by dokonać biograficznego rachunku zysków i strat ${ }^{46}$. Powstaniec warszawski, porażony swoją bezsilnością w walce z Niemcami w sierpniu 1944 roku, zazdrościł Polakowi deportowanemu do Kazachstanu, że ten - choć doznał bólu wypędzeń na wschód - dostał jednak od Rosjan prawdziwą broń do ręki i dlatego - inaczej niż powstańcy w Warszawie - mógł skutecznie bić się z Niemcami o Polskę, na co były deportowany odpowiadał czarnym rachunkiem swoich krzywd: utrata małej ojczyzny za Bugiem, „wydarcie z korzeniami” z kresowego Polesia, śmierć dzieci, osłabienie więzi z żoną, która nie została deportowana, a po powrocie do Polski doznawanie skrytej, pogardliwej niechęci ze strony Polaków, którzy polskich zesłańców z armii Berlinga chętnie uważali za pachołków Rosji, „zaprzańców”, co to wyrzekli się wschodniej połowy Polski, wreszcie życie w wiecznym strachu przed Niemcami, którzy mogą w każdej chwili wrócić na polskie Ziemie Zachodnie, bo traktat pokojowy nie został podpisany, choć samo masowe zasiedlenie ziem poniemieckich przez Polaków zza Buga Auderska przedstawiała jako prawdziwy sukces ogólnonarodowy.

W zgodzie z polskimi pisarzami wieku XIX, a wbrew czarnej - współczesnej i dawnej - legendzie zesłań Auderska wskazywała teź na dobre przyjęcie deportowanych Polaków przez ludność miejscową w Kazachstanie, brak aktów wrogości, ponadnarodową solidarność w obliczu okrutnej, azjatyckiej przyrody, a nawet zawieranie małżeństw mieszanych, które po wojnie wcale nie chciały się przenieść do Polski. W Babim lecie część wypędzonych na wschód Polaków wolała w 1945 roku wrócić z zesłania w głębi Rosji na sowieckie Polesie, byleby tylko nie zamieszkać we „wrogiej” im, jak to odczu wali, Polsce Centralnej, wybrała więc kresową „tutejszość”, nawet jeśli miała być to „tutejszość” pod władzą ZSRR.

Powieść Auderskiej odbiegała od tonu wielu polskich narracji deportacyjnych w jeszcze jednym istotnym punkcie: aksjologia bilansu biograficznego była w niej budowana z perspektywy plebejskiej, co w polskiej literaturze, w której dominanta inteligencka jest bardzo silna, nie zdarza się często.

Jeszcze dalej w rewizji utrwalonej w polskiej kulturze oceny masowych deportacji na wschód poszedł Igor Newerly. W roku 1980 w powieści Wzgórze

$46 H$. Auderska Babie lato, s. 267-269. 
błękitnego $s n u^{47}$ przedstawił losy Polaka deportowanego na Syberię, który po odbyciu paroletniej katorgi założył w tajdze farmę, żywcem przypominającą leśne siedlisko z Waldena Henry'ego Davida Thoreau. Syberia jako ekologiczny raj zesłańców wrośniętych w społeczność lokalną, kraina sukcesu gospodarczego i udanego życia osobistego deportowanych, z której to właśnie powrót do polskiego Heimatu staje się dla polskiego wygnańca bolesną traumą, bo warszawscy Polacy omijają z daleka rodaka z Syberii, który co prawda bił się o wolność Polski, ale teraz - po wieloletnim pobycie na zesłaniu - wydaje się niebezpiecznie „obcy”. Logika pozytywnego bilansu biograficznego deportacji burzyła tutaj polskie stereotypy, przedstawiając wypędzenie na wschód właśnie jako szansę na pełną samorealizację, a powrót zesłańca do Polski niemal jako jego osobistą klęskę, co miało podłoże autobiograficzne, bo sam Newerly w młodości przebywał w Rosji, o czym na zawsze zachował w swojej pamięci dobre wspomnienia.

Prawdziwie zaś szokującym wariantem polskich narracji o masowych wypędzeniach na wschód, radykalnie burzącym poetykę negatywnego bilansu biograficznego Golgoty syberyjskiej, stała się powieść Andrzeja Czcibora Piotrowskiego Rzeczy nienasycone ${ }^{48}$, gdzie zesłanie ośmioletniego polskiego chłopca do Kazachstanu - inaczej niż w dominujących narracjach - staje się rajskim wtajemniczeniem w świat erotyki i wiecznej kobiecości. Trudno znaleźć w literaturze niemieckiej pisarza, który kiedykolwiek odważyłby się na tak daleko posuniętą swobodę w podejściu do traumatycznego doświadczenia wypędzeń i deportacji ${ }^{49}$.

Fundamentem aksjologii bilansu biograficznego wypędzeń była paradoksalna teza: „człowiek nigdy nie wie całej prawdy o swoim losie” w chwili, gdy go przeżywa, dopiero dalszy bieg życia odsłania prawdziwy sens zdarzeń, w jakich uczestniczymy ${ }^{50}$. W takim ujęciu zderzały się ze sobą dwa plany czasowe: czas niewiedzy (czy wiedzy pozornej) człowieka wypędzanego i czas wiedzy późniejszej, która często całkowicie zaprzeczała rozpoznaniom i odczuciom doznawanym w chwili wypędzenia.

47 I. Newerly Wzgórze błękitnego snu, Czytelnik, Warszawa 1986.

48 A.Cz. Piotrowski Rzeczy nienasycone, W.A.B., Warszawa 2010.

W Wielbłądzie na stepie (Czytelnik, Warszawa 1987) doświadczenie wypędzenia u paroletniego polskiego dziecka, deportowanego w latach 1941-1942 do Kazachstanu, przeniknięte "duchem wielkiej przygody życia", zostało przedstawione przez Jerzego Krzysztonia jako czas wzbogacającego procesu adolescencji, bolesnego, ale i egzystencjalnie owocnego. 
Podobne ujęcie czasu pojawiało się w mojej gdańsko-wileńskiej Krótkiej historii pewnego żartu ${ }^{51}$. Mój ojciec, który jest prototypem jednego z bohaterów tej książki, wypędzony w 1945 roku ze wschodniej części przedwojennej Polski, przez wiele lat czuł wdzięczność do Losu (Stalina?), że jakimś cudem dano mu moźliwość opuszczenia w deportacyjnym wagonie stron rodzinnych zajętych przez ZSRR i nie wywieziono go w przeciwnym kierunku, na Syberię, tylko pozwolono wyjechać do Polski Centralnej. Myśl, że mógłby zostać zmuszony przez Rosjan do pozostania na całe życie w sowieckim Wilnie, budziła w nim przerażenie. Z jednej więc strony cierpiał, bo z bólem opuszczał swój utracony na zawsze polsko-wileński Heimat, z drugiej był szczęśliwy, że nie musi do końca życia mieszkać na sowieckiej Litwie albo na Syberii, jak tysiące Polaków, którzy tam pozostali. Ze wszystkich alternatyw losu wypędzenie z zajętych przez ZSRR kresów wschodnich na zachód, na polskie Pomorze, wydawało mu się rozwiązaniem najlepszym $\mathrm{z}$ możliwych ${ }^{52}$. W niemieckich narracjach deportacyjnych niewielu Niemców z Gdańska, Olsztyna, Szczecina i Wrocławia myślało podobnie, Bogu dziękując za to, że w latach 1945-1950 jakimś cudem los (Stalin?) dał im możność „ucieczki” w deportacyjnych wagonach z komunistycznego więzienia narodów na zachód, za Odrę i dalej, zamiast zmusić ich do życia w „czerwonym” Gdańsku czy Wrocławiu albo w zimnych okolicach pod zorzą polarną.

\section{Bilans biograficzny a wychodzenie z traumy podporządkowania}

Aksjologię bilansu biograficznego w narracjach deportacyjnych komplikowała sprawa wychodzenia z traumy podporządkowania. Sprawa ta nie pojawiała się jednak w narracjach polskich dotyczących deportacji na wschód. Trudno tu mówić o elementach świadomości postkolonialnej.W polskich i niemieckich narracjach deportacyjnych, mówiących o zetknięciu z Rosją, dawało znać o sobie w istocie podobne poczucie górowania kulturalnego, gospodarczego, cywilizacyjnego nad mentalnością , azjatyckich" zdobywców, jakiego nie było np. u mieszkańców dawnych kolonii brytyjskich czy francuskich, gdzie

S. Chwin Krótka historia pewnego żartu. Sceny z Europy Środkowowschodniej, Oficyna Literacka, Kraków 1991. Refleksy tej sprawy pojawiają się także w powieści Hanemann.

52 Złożoność - a nawet wewnętrzną sprzeczność - postaw Polaków deportowanych z Kresów Wschodnich do Polski Centralnej w latach 1944-1947 świetnie pokazał w swojej powieści Zbigniew Żakiewicz (Wilio, w głębokościach morza, s. 151-172). 
podporządkowani wielką pracą wewnętrzną musieli z trudem dopracowywać się mocnego poczucia wartości własnej kultury ${ }^{53}$.

Katalogi form niższości żywiołu azjatyckiego stanowią żelazny punkt zarówno w relacjach polskich, jak i niemieckich. W narracjach kazachstańskich zniewoleni Polacy realizują w warunkach deportacji w istocie polską misję cywilizacyjną na wschodzie wśród prymitywnej ludności lokalnej, wprowadzając ton europejski do azjatyckiej przestrzeni społecznej. Sceny śledztwa w NKWD uporczywie powtarzają ten sam obraz przesłuchiwanego Polaka czy przesłuchiwanej Polki, którzy mają do czynienia z funkcjonariuszem policji politycznej, prostakiem niezdolnym do racjonalnego myślenia. Podporządkowanie miało więc tutaj charakter wyłącznie zewnętrzny. Józef Czapski silnie eksponował fakt, że więźniowie w Starobielsku, choć zepchnięci na dno podporządkowania, imponowali administracji sowieckiej wykształceniem i umiejętnością natychmiastowego zbudowania w obozie dla deportowanych jeńców wartościowych form życia intelektualnego, często na poziomie uniwersyteckim ${ }^{54}$. W narracjach niemieckich z prawdziwą satysfakcją odnotowywano obraz Niemca z terenów Pomorza zajętych przez Rosjan, który - choć w roku 1945 zostaje zepchnięty do roli politycznego niewolnika - samym swoim wyglądem, postawą, gestem i słowem potrafi wzbudzić respekt w Rosjanach czy Azjatach, przypominając im skutecznie, jakie jest ich prawdziwe miejsce, niczym właściciel plantacji w Missisipi wobec wyzwolonych murzyńskich niewolników. Nawet u antynazistowskiej Libussy von Krockow stary pruski ojciec - skądinąd traktowany przez nią jako antagonista - budzi podziw, gdy - bezbronny i chory - paroma słowami potrafi postawić na baczność rosyjskiego komendanta ${ }^{55}$. Podobnie

53 O trudnym uwalnianiu się skolonizowanych od narzuconej podrzędnej tożsamości kolonialnej zob. np. G.Ch. Spivak Can the Subaltern Speak?, w: Marxism and the interpretation of Culture, ed. C. Nelson, L. Grossberg, Macmillan, London 1988; F. Fanon Wyklęty lud ziemi, przeł. H. Tygielska, przedm. E. Rekłajtis, posł. J.-P. Sartre, PIW, Warszawa 1985.

54 Czapski podziwiał Polaków, którzy ból deportacji potrafili rozładować naukowym zainteresowaniem przyrodą rosyjską, a nawet "głęboką radością" z badań przyrodniczych, $i$ kontrastował z takimi Polakami masę ludzi „zmiażdżonych przez deportacje, niezdolnych do cichej równowagi ducha", z uznaniem pisząc np. o polskim inteligencie, który w dniach ostatecznej klęski Polskiw 1939 roku potrafiłz entuzjazmem planować odbudowę Gdyni (J. Czapski Na nieludzkiej ziemi, s. 17-21).

Podobną rolę wyznaczyła Libussa von Krockow pani Liebe, która bez trudu potrafi zdominować rosyjskich oficerów, ale nie ma żadnego sposobu na prymitywnego "napuszonego" burmistrza polskiego (Ch. Graf von Krockow Czas kobiet..., s. 73). 
w narracjach niemieckich przedstawia się sprawa - odczuwanej jako naturalna - psychicznej dominacji Niemców nad robotnikami przymusowymi ze wschodu - także po ich wyzwoleniu przez Rosjan. W aksjologii bilansu biograficznego Niemcy - nawet zepchnięci na dno - nigdy nie zostają skolonizowani do końca, co chętnie podkreślają narratorzy. Tymczasem zachowania Polaków na terenach poniemieckich są zwykle w relacjach niemieckich przedstawiane jako prymitywna zemsta byłych niewolników, całkowicie zdominowanych przez postkolonialne urazy, chociaź czasem wspomina się także o polsko-niemieckiej solidarności klas wyższych i wykształconych.

Inaczej wygląda to z perspektywy polskiej. W narracjach deportacyjno-osiedleńczych łagodzona czy przemilczana jest sprawa brutalnego charakteru wypędzeń Niemców za Odrę. Ideologii sprawiedliwej zemsty dziejowej towarzyszy tu poczucie cywilizacyjnej niższości strony polskiej, maskowane w różny sposób, ale także odreagowywane różnymi sposobami. Dominującym toposem, który pozwala „wymazać” obraz Polaka jako postkolonialnego niewolnika mszczącego się na swoich byłych panach, jest w polskiej literaturze (i polskim filmie) topos całkowicie pustych ziem poniemieckich, swobodnie i bezkrwawo zajmowanych przez polskich osadników, całkowicie sprzeczny z relacjami niemieckimi, wskazującymi na ogromną liczbę Niemców, którzy pozostali w swoich miastach i wsiach, poniewaź nie zdążyli uciec przed Armią Czerwoną za Odrę.

Także dlatego polska opowieść o deportacjach z Kresów i Syberii na Ziemie Zachodnie jest czasem stylizowana na podobieństwo wędrówki amerykańskich osadników kolonizujących „pusty” Dziki Zachód, gdzie rolę Indian, napadających na farmy białych ludzi, odgrywają atakujące z ukrycia resztki „niewidzialnego" Werwolfu ${ }^{56}$. Powrót części Niemców do miejsc zamieszkania po zakończeniu działań wojennych jest odczuwany przez Polaków jako powtórna inwazja niemiecka ( $u$ Auderskiej porównana do inwazji myszy z legendy o Popielu), która zanieczyszcza „otwartą” ziemię obiecaną, dlatego po Niemcach trzeba szorować mydłem całe niemieckie domy. Obroną przed interioryzacją pozycji subalterna są także polskie stereotypy rasistowskie, biologizujące przyrodzoną fizyczną odmienność Niemców, tak jak stereotypy nazistowskie biologizowały przyrodzoną fizyczną odmienność Słowian. Nawet ciało niemieckie jest inne niż ciało polskie - budzi fizyczny

56 Wersją filmową tego „amerykańskiego" toposu deportacji był antyniemiecko-piastowski western filmowy z 1964 roku Prawo i pięść w reżyserii Edwarda Skórzewskiego i Jerzego Hoffmana. 
wstręt $^{t^{57}}$. Syndrom psychicznego „poparzenia” przez niemieckość z czasów okupacji każe osiedleńcom alergicznie reagować na wszystko, co niemieckie, szczególnie na samo brzmienie niemieckiej mowy. Repatrianci ze wschodu stosują też strategie regresywne, by rozładować dominującą obcość nowych poniemieckich miejsc osiedlenia. U Auderskiej przybysze z Polesia cywilizacyjną odmienność niemieckiej infrastruktury przezwyciężają gestami magicznymi: w miejsce niemieckiego pieca stawiają piec ruski, na którym chcą spać tak, jak spali u siebie, na Kresach. Wolą też glinianą polepę od niemieckiej podłogi. Wszystkie te pozornie komiczne zachowania polskiej ludności napływowej są skutkami brutalnej niemieckiej akcji kolonizacyjnej, która wżarła się w polską podświadomość i wciąż w niej nurtuje podskórnymi urazami.

Mitologia sprawiedliwego rewanżu, ozdobiona skrzydłami piastowskich orłów, pozwala w jakimś stopniu rozplątać bolesny splot wrogości, potrzeby zemsty, poczucia niższości i krzywdy. Wyższościowa postawa Niemców, którzy co prawda zostali zgnieceni militarnie, ale w oczach Polaków pozostają nadal tymi samymi Niemcami, wciąż odbierana jest jako raniąca. Ciekawym toposem w narracjach polskich jest obraz niemieckich zwierząt, które nawet na terenach zajętych po zakończeniu wojny przez ludność polską pozostają dumnie niemiecko-hitlerowskie.

Wyraźne podłoże urazowe mają sceny, w których nienawiści do bauera towarzyszy zawistny podziw dla niemieckiej sztuki gospodarowania. W opowiadaniu byłego przymusowego robotnika, Henryka Worcella, Polacy chcą pozbyć się Niemców, a równocześnie boją się, jak po ich odejściu poradzą sobie przy żniwach, bo nie wiedzą, jak obsługiwać poniemieckie maszyny rolnicze. $\mathrm{Z}$ satysfakcją odnotowuje się rozpad więzi w rodzinach niemieckich, a więc wszystko, co Niemców osłabia. Równocześnie ważną rolę odgrywają gesty wspaniałomyślnego wybaczenia i pomocy dawnym prześladowcom przy podkreślaniu, że Niemcy wcale na to nie zasługują. Nawet uniżoność i posłuszeństwo pokonanych odbierane są jako gesty obraźliwej wyniosłości i pychy.

57 Wopowiadaniu Worcella polską odrazę budziła sama "typowo niemiecka" cielesność: "Włosy rude, twarz jakby z zabarwionej papryką galarety, tyłek płaski, nisko opuszczony". Niemka zaś pojawiała się jako "ruda diablica”. (Wotan odjedzie pociggiem, w: Polska nowela współczesna, t. 1, Wydawnictwo Literackie, Kraków 1975, s. 365). Fizyczna odraza popychała Polaków do obsesyjnej czystki higienicznej całych poniemieckich domów - mycia wszystkiego mydłem, piaskiem, sidolem albo ogniem. Worcell dostrzegał u Polaków na Ziemiach Zachodnich rysy rasizmu fizjonomicznego, wymierzonego w nację germańską, ale także pełen ambiwalencji, skomplikowany splot sympatii i nienawiści wobec Niemców jako konkretnych osób. 
Dążeniu do indywidualizacji postaci Niemców towarzyszy przeciwstawne dążenie do ideologicznego ujednolicenia, zmieniające Niemców w tłum, który odchodzi za Odrę z zachowaniem pańsko-hitlerowskich manier ${ }^{58}$.

\section{Alssjologia deportacyjna "ojczyzny ideologicznej"}

Osobną sprawą, wartą uważnego zbadania, jest to, jak doświadczenie deportacji na wschód, a potem ze wschodu na zachód, do Polski Centralnej, rysowało się w biografiach duchowych (i twórczości) polskich komunistów. Jeśli aksjologiczną podstawę większości narracji deportacyjnych - zarówno polskich, jak i niemieckich - stanowiła zwykle kategoria ojczyzny etnicznej, ukazująca wypędzenie jako wyrwanie deportowanych z miejsca identyfikowanego z konkretnym ludem, kulturą, religią, przyrodą, obyczajem, ziemią, a podstawą wartościowania traumatycznych wydarzeń historycznych była metafora wegetatywno-biologiczna człowieka jako ukorzenionego drzewa, wyrywanego z ziemi przez złe moce historii59, w przypadku polskich komunistów wszystko wyglądało inaczej. Kluczową strukturą myślenia było tu zdecydowane przeciwstawienie „fałszywej” ojczyzny etnicznej i „prawdziwej" ojczyzny ideologicznej, co w obrazie deportacji zmieniało właściwie wszystko.

Tragiczne losy Polaków deportowanych do ZSRR i ich nostalgię za utraconą ojczyzną - właśnie jako ojczyzną etniczną - zostały opisane przez wielu pisarzy związanych z Armią Andersa. Już jednak w okresie lwowskim, a więc w 1939 roku i na początku lat 40., część polskich pisarzy dawała pozytywny obraz deportacji ludności kresowej do ZSRR, przedstawiając wypędzenia

58 W Babim lecie polscy osadnicy są oburzeni nawet tym, że dumne Niemki bez zgody Polaków naprawiają swoje płoty. Niemcy mają "twarze z kamienia" (121), spluwają na widok polnische Wirtschaft, Polaków irytuje "szwargot" niemiecki, kobieta niemiecka wydaje „wrzask esesmański" (122), „parszywy wrzask". Niemieckie dzieci z opaskami ze swastyką na ramieniu ośmieszają Polaków i bawią się w ich rozstrzeliwanie. Szwabska pycha sprawia, że Niemcy niszczą własne gospodarstwa, by nie dostały się w polskie ręce. "Cholerne bauery" (135) podstępnie podgryzają "tych zza Buga, jak myszy korzenie naszego zboża" (163). Za karę za takie zachowanie deportowani ze wschodu Polacy zapędzają Niemców do prac porządkowych. Tak w powieści Auderskiej Niemców widzi Polak deportowany z Polesia na Ziemie Zachodnie, któremu Niemcy zabili rodzinę. Ale oprócz tego Auderska pokazywała damsko-męskie związki mieszane i tworzenie się wspólnego polsko-niemieckiego życia. Niemiecki ksiądz katolicki uczy się języka polskiego, by wygłaszać kazania do ludności deportowanej ze wschodnich terenów byłej II Rzeczypospolitej (s. 194), a wiejski cmentarz staje się wspólny, polsko-niemiecki.

59 Taki metaforyczny obraz został umieszczony na okładce Wypędzonych ze wschodu. 
jako... upragnioną wędrówkę miejscowych ludów do prawdziwej ojczyzny ideologicznej ${ }^{60}$. Dodatkowo pisarze pochodzenia żydowskiego, prześladowani przed wojną przez władze i radykalną prawicę narodową za komunizm, ruch na wschód odbierali jako szansę ocalenia przed Holokaustem (np. Adolf Rudnicki). W powieści Wandy Wasilewskiej Tęcza ludność białoruska z polskich kresów, nienawidząca - jak przedstawiała to pisarka - przedwojennej Polski, szczerze marzyła o wejściu do ZSRR. Bohater powieści Płomień na bagnach, ginął przy próbie ucieczki z Polski do czerwonej Rosji, tak bardzo chciał się tam znaleźćć.

W opowiadaniach Elżbiety Szemplińskiej „polscy bieżeńcy”, którzy uciekli z Polski Centralnej, zajętej przez wojska niemieckie, na tereny zajęte przez Armię Czerwoną, spotykali się w ZSRR z sympatią, jakiej nigdy nie zaznali w Polsce ${ }^{62}$. Lucjan Szenwald, który po ucieczce z Warszawy dobrowolnie

60 Zob. J. Święch Literatura polska w latach II wojny światowej, PWN, Warszawa 1997, s. 183-185.

61 W powieści Wasilewskiej Gwiazdy w jeziorze komunista, świadek wywózki kobiety, którą kochał, uznaje jej wypędzenie przez sowietów z Polesia na wschód za słuszne i zgodne z nieuchronną logiką dziejów: „I patrząc, jak odjeżdża wóz w kierunku Sinic, w kierunku stacji [...] poczuł w sobie nagle serce męskie i twarde. Jeszcze raz stwierdził surowość dni, które szły - i które nie mogły być inne, niż były" (W. Wasilewska Pisma zebrane, t. 3, Wydawnictwo MON, Warszawa 1956, S. 558).

62

W opowiadaniach z tomu Pożegnanie (Wydawnictwo Literatury w lęzykach Obcych, Moskwa 1943) Szemplińska dokumentowała losy ludności polskiej i ukraińskiej w dniach "wyzwolenia" zachodniej Ukrainy przez Armię Czerwoną. Opierając się na własnych doświadczeniach z przekraczania granicy polsko-sowieckiej w 1939 roku, akcentowała przychylność i sympatię Kraju Rad dla uciekinierów z Polski (opowiadanie Uśmiechnij się). W opowiadaniu List do Warszawy ("Nowe Widnokręgi" 1941 nr 8, s. 6-17) jedna z bohaterek, Polka, wyrażała nadzieję, że "wyzwolenie" całej Polski przez Armię Czerwoną nastąpi już w 1940 roku. Tytułowe opowiadanie tomu, Pożegnanie, było zmodyfikowaną wersią opowiadania Pożegnanie z synem, które ukazało się we wrześniu 1940 na łamach ukraińskiego miesięcznika "Literatura i Mistectwo" (1940 nr 1). Wopowiadaniu tym Polak, syn kolejarskiej rodziny, chciał wstąpić do Armii Czerwonej, by pomścić brata, który bezsensownie poległ w 1939 roku, broniąc kapitalistycznej Polski. Kluczowym tekstem dla zrozumienia postawy Szemplińskiej z tamtego okresu był jej wiersz napisany we Lwowie w 1939 roku Prawdziwa ojczyzna ("Czerwony Sztandar" 1939 nr 67, s. 3). Podobne treści pojawiały się w Pierwszych dniach, które Szemplińska napisała wspólnie z mężem, Zygmuntem Sobolewskim ("Almanach Literacki” 1941 nr 1). O prozie Szemplińskiej z okresu lwowskiego zob. K. Woźniakowski Prasa - Kultura - Woina. Studia z dziejów czasopiśmiennictwa, kultury literackiej i artystycznej lat 1939-1945, Seria druga, Kraków 2005, s. 236-254; M. Inglot Polska kultura literacka Lwowa lat 1939-1941. Ze Lwowa i o Lwowie. Lata sowieckiej okupacji w poezji polskiej. Antologia utworów poetyckich w wyborze, Towarzystwo Przyjaciół Polonistyki Wrocławskiej, Wrocław 1995, s. 122-123, zob. także: M. Inglot Spór o Wrzesień w poezii polskiej lat 1939-1941 we Lwowie, "Pamiętnik Literacki" 1990 nr 1, S. 205-240; J. Chłosta Polskie życie literackie we Lwowie 1939-1941 w świetle oficjalnej prasy polskojęzycznej, Wydawnictwo UWM w Olsztynie, 
przeszedł na tereny zajęte przez Armię Czerwoną, masowe deportacje Polaków w głąb Rosji akceptował w pełni, Syberię uznał za swoją prawdziwą ojczyznę, a przedstawicieli rządu londyńskiego za agentów i szpiegów Zachodu. Opuszczenie Polski i pobyt w ZSRR, co dla większości Polaków było doświadczeniem traumatycznym, traktował jako szansę na radykalną przemianę osobowości, zwalczenie w sobie dawnego „ja”, uzdrowienie psychiki z resztek „Polski powersalskiej" ${ }^{63}$.

Podobnie wyglądało to u Broniewskiego. Aresztowanie 24 stycznia 1940 roku, ciężkie przeżycia więzienne i deportacja w głąb Rosji, do Saratowa i Ałma Aty, wstrząsnęły nim bardzo silnie, ale w żadnym stopniu nie naruszyły jego komunistycznego światopoglądu, choć w Palestynie powstały bardzo gorzkie deportacyjne wiersze antysowieckie. Polscy komuniści, którzy - tak jak Broniewski - po przejściach wojennych znaleźli się w kraju, two rzyli w Polsce Ludowej nieformalny klan czerwonych Sybiraków, zajmujący w hierarchiach władzy najwyższe miejsca. To właśnie doświadczenie syberyjsko-deportacyjno-więzienne - bolesne, ale w ostateczności odbierane jako pozytywne - w znacznym stopniu cementowało spójność tego środowiska przeciwko narodowej „frakcji partyzantów” Moczara w PZPR. Ważną rolę w postawie polskich pisarzy wobec wypędzeń na wschód odgrywało także nastawienie marksistowskie, wedle którego deportacje należało oceniać jako doświadczenie przykre, ale całkowicie uzasadnione w świetle historycznej konieczności procesu dziejowego.

\section{Aksjologia bilansu historycznego wypędzeń}

Aksjologia bilansu historycznego wypędzeń wychodziła poza tak rysującą się perspektywę indywidualnego rachunku zysków i strat. Tutaj miejsce

Olsztyn 2000; B. Czajkowski Lwowska pierekowka, "Gazeta Wyborcza” 2002 nr 233, s. 19-20; J. Święch Literatura polska w latach II woiny światowej, PWN, Warszawa 1999, s. 185.

63 W poemacie Pożegnanie Syberii z 1943 roku (L. Szenwald Utwory poetyckie, Książka i Wiedza, Warszawa 1950) czytamy: „Mnie tu gościna była: dach nad głową, / Czerstwy kęs chleba, szorstki uścisk dłoni, / Koleżeństwo w robocie. Ja tej ziemi / Zawdzięczam odnowienie. Jej radosny / Krok mój zawdzięczam" (s. 164). Syberia - pisał Szenwald - we mnie "Spaliła resztki zawiłych wykwintów, / I wróciła postawę żołnierza" (s. 165). Stalina, który deportował tysiące Polaków na Syberię, uważał za „Tego, co ogrzał ich i wskrzesił”, ponieważ stworzył w Rosji polskie wojsko, oni zaś "Ugryźli rękę - marne kundle" (s. 160). Syberia z lat 40. XX wieku to w poezji Szenwalda "Akord radości, woli i zwycięstwa", symbol zjednoczenia dawnych wrogów - Polaków i Rosjan - w obliczu śmiertelnego zagrożenia niemieckiego. 
jednostkowego losu zajmował rachunek zysków i strat, jakie odniosła/poniosła deportowana wspólnota, a nawet cała społeczność narodowa.

Rachunek ten miał często charakter paradoksalny. Oto np. brutalna deportacja 17 ooo Żydów - obywateli polskich, którzy zostali wypędzeni w listopadzie 1938 roku z hitlerowskich Niemiec do Polski - właśnie przedłużyła (a nawet ocaliła) życie wielu z nich, poniewaź gdyby do tej deportacji nie doszło, Żydzi, którzy pozostaliby w Niemczech, trafiliby najpewniej do obozów koncentracyjnych (np. Dachau), gdzie zgładzono by ich dużo szybciej? ${ }^{64}$ Czym zatem w sensie aksjologicznym był sam akt brutalnego wypędzenia, jeśli mógł mieć tak pozytywne skutki? I jaką miarą go oceniać? Miarą intencji sprawców (nikczemnych), miarą bezpośrednich skutków działania (udręka wypędzonych w Zbąszynie) czy raczej miarą odległych w czasie skutków historycznego zdarzenia, których w chwili wypędzenia nikt z wypędzonych nie potrafił przewidzieć, ponieważ nikt nie zdawał sobie sprawy, że dostaje od losu paradoksalną szansę ocalenia?

Wywózki Polaków na wschód w latach 1939-1940 były doświadczeniem bolesnym, lecz ostatecznie miały skutek pozytywny, bo deportowani Polacy (i Polska jako państwo) bardzo skorzystali na terytorialnej rekompensacie, dostając od Stalina w zamian za wschodnie deportacje i utratę Kresów wysoko cywilizowane ziemie poniemieckie - tak w swoich wspomnieniach bilans historyczny wypędzeń przedstawiali polscy komuniści, bagatelizując równocześnie ból deportacji i eksterminacyjne praktyki w gułagach. U Auderskiej to właśnie brutalna sowiecka deportacja mieszkańców polskiego Polesia do Kazachstanu ocala wielu z nich przed tragicznym losem ich rodzin, które giną z rąk Niemców, właśnie dlatego, że nie zostały deportowane przez NKWD na wschód.

Auderska stawiała sprawę jasno. Tylko wejście sowietów na polskie Kresy razem z dywizją kościuszkowską ocaliło ludność miejscową przed śmiercią z rąk esesmanów i „rezunów” Stepana Bandery, ponieważ to nikt inny, jak tylko Armia Czerwona zamroziła kresowe rzezie, skutecznie rozdzielając bagnetem nienawidzące się narody, a także blokując na długie lata możliwość powtórzenia się syndromu rzezi wołyńskiej, więc choć cena psychologiczna i materialna rosyjskiej inwazji była ogromna, w ogólnym rachunku historycznych zysków i strat opłaciło się znieść ten ból.

64 W. Olejniczak, I. Skórzyńska Do zobaczenia za rok w jerozolimie - deportacie polskich Żydów w 1938 roku z Niemiec do Zbąszynia, Regards Multiples, Fundacja TRES, Zbąszyń 2012. J. Tomaszewski Auftakt zurVernichtung: Die Vertreibung polnischer Juden aus Deutschland im /ahre 1938, Fibre, Osnabrück 2002. 
Srokowski podważał to rozumowanie. Zgoda, polskie wioski na Kresach - tak rzecz przedstawiał w Repatriantach - były ratowane przed terrorem banderowców nie tylko przez oddziały samoobrony Armii Krajowej, lecz także przez oddziały sowieckiej partyzantki, ale sowieci ratowali ludność miejscową tylko po to, by ją potem przerobić na kołchozowych niewolników albo wywieźć za Ural.

Aksjologia bilansu historycznego ujmowała wypędzenia jako element szerszej sytuacji geopolitycznej, łącząc refleksję polityczną z refleksją historiozoficzną. Była aksjologią wielkich liczb, nie tylko losów indywidualnych. Rozważała deportacje w perspektywie ich skutków dla mas ludności, a nawet dla całych państw i narodów.

\section{Aksjologia "historii alternatywnej"}

Perspektywa „historii alternatywnej”, w kilku punktach bliska aksjologii bilansu historycznego, w istotny sposób ją przekracza: chce poznawać historię rzeczywistą w lustrze moźliwych jej przebiegów. Jej punktem wyjścia jest odrzucenie kategorii konieczności historycznej. To, co zdarzyło się kiedyś, nie musiało się nieuchronnie zdarzyć, moźliwy był także inny bieg wypadków, pytanie, dlaczego ten inny bieg wypadków nie nastąpił, skłania do badania złożonej genezy tego, co się stało. Kluczowym pojęciem jest tu pojęcie nexus point, tak je definiuje w swoich studiach np. Karen Hellekson ${ }^{65}$. Aksjologia taka stawia pisarza przed ryzykownym wyzwaniem, bo może uderzać nie tylko w przyzwyczajenia poznawcze, ale także w utrwalone postawy uczuciowe wielu ludzi, przyzwyczajonych do utartych - moralnie i politycznie usankcjonowanych - sposobów oceny masowych deportacji w XX wieku. Chodzi bowiem o ustalenie nie tylko tego, co i jak się zdarzyło w przeszłości, ale też tego, czego prawdopodobnie zdołaliśmy - z korzyścią dla siebie bądź ze stratą - unikną ${ }^{66}$.

65 Zob. K. Hellekson The Alternate History: Refiguring Historical Time, Kent State University Press, Kent, Ohio-London 2001. Alternatywna historia jako eseistyczny eksperyment myślowy oparty na metodzie analizy historycznej zob. np. P. Zychowicz Pakt Ribbentrop-Beck, czyli jak Polacy mogli u boku III Rzeszy pokonaćZwiq̨zek Sowiecki, Rebis, Poznań 2012.

66 Według Geoffreya Winthrop-Younga historie alternatywne budowane są w przestrzeni możliwości między poczuciem straty (niewykorzystanie potencjału dawnych wydarzeń przez historię późniejszą) a afirmacją historii dokonanej jako najlepszego z możliwych wariantów rozwoju dawnych zdarzeń. Zob. Fallacies and Thresholds: Notes on the Early Evolution of Alternate History, "Historical Social Research: Counterfactual Thinking as Scientific Method" 2009 Vol. 34, No. 2 (128). 
Z tej perspektywy prawdziwym wyzwaniem aksjologicznym dla literatury jest pytanie: jak wyglądałby dzisiaj świat, jak wyglądałaby dzisiaj Europa, gdyby w XX wieku nie doszło do masowych wypędzeń? ${ }^{6}$ I jak ów świat alternatywny, którego możliwość takie pytanie zakłada, mógłby zostać skonstruowany w dziele literackim? Z jakich sytuacji i przebiegów zdarzeń? Czy byłby to świat lepszy, czy gorszy od dzisiejszego? Z pewnością nie jest to pytanie dla historyków o nastawieniach tradycyjnych, którzy wolą stąpać po twardym gruncie faktów, ale jest ono najzupełniej stosowne dla pisarzy (i badaczy literatury), ponieważ jego warunkiem jest ryzykowna transgresja wyobraźni i stereotypów aksjologicznych, które wciąż organizują nasze myślenie o doświadczeniu wypędzeń z połowy XX wieku. Istota sprawy tkwi w pytaniu, które rzutuje na organizację świata przedstawionego: jakimi miarami oceniać XX-wieczne deportacje? Istnieje bowiem miara indywidualnej krzywdy, miara zranionej dumy narodowej, miara politycznego uprzedmiotowienia, miara sprawiedliwości dziejowej, miara odwetu, miara wyrównania krzywd, miara ekumenicznego pojednania, miara terytorialnej i ekonomicznej straty. Są to miary ze sobą nieuzgadnialne. Jest jeszcze jedna miara, która wykracza poza pozostałe, stawiając literaturę przed wyzwaniem radykalnym: czy w ogólnym historycznym rozrachunku powojenne wypędzenia były rujnujące czy raczej korzystne dla Europy i świata?

Zacznijmy więc od Gdańska, miejsca mi najbliższego ${ }^{68}$.

Jak w roku 1989 rozwinęłaby się sytuacja w Gdańsku, w którym nie doszłoby w latach 1945-1947 do wypędzeń ludności niemieckiej, w Gdańsku więc - tak mógłby się w literaturze "alternatywnej" rysować jego obraz dwujęzycznym i dwunarodowym, w którym pod żelaznym parasolem komunizmu żyłoby we względnej zgodzie około 200000 Polaków i około 300000 Niemców? Co stałoby się po rozpadzie komunizmu? Jaka literacka "fabuła”

67 Model "historii alternatywnej", który tutaj buduję, to obraz Europy po II wojnie światowej, w której na mocy porozumień w Teheranie, Jałcie i Poczdamie zostały przesunięte przedwojenne granice państw tego regionu (do stanu obecnego), lecz zwycięscy alianci nie podjęli decyzji o przymusowych masowych przemieszczeniach ludności. Byłby to zatem obraz Europy, w której geograficzne usytuowanie wspólnot etnicznych pozostało - mimo przesunięć granic - takie samo jak przed wojną.

Obraz ewentualnego rozwoju sytuacji w Gdańsku po 1989 roku buduję na podstawie uniwersalnego modelu sytuacji kryzysowej w miastach dwunarodowych, biorąc pod uwagę sytuację w irlandzko-brytyjsko-katolicko-protestanckim Belfaście, dwunarodowej i dwureligijnej lerozolimie, chrześcijańsko-muzułmańskim Sarajewie z czasów wojny jugosłowiańskiej w latach 90. XX wieku, sytuację w Kosowie po upadku komunistycznego państwa losipa Broz Tito oraz sytuację w miastach na Krymie i w Donbasie w latach 2014-2015. 
zdarzeń mogłaby się rozwinąć? Czy w wolnej, demokratycznej Polsce społeczność niemiecka zaczęłaby domagać się rozszerzenia swoich praw? Pierwsze demokratyczne wybory do władz miasta wygraliby - choćby z powodów statystycznych - zapewne obywatele polscy niemieckiego pochodzenia. Czy w polskiej i niemieckiej społeczności Gdańska doszliby do głosu działacze polityczni, skłonni do rozwiązań idących dalej? Czy wśród gdańskich Niemców pojawiłaby się grupka, a potem ruch, który domagałby się zwiększenia autonomii politycznej Gdańska, śniący np. o „obywatelstwie gdańskim” czy nawet o „narodowości gdańskiej”, a więc - na początek - o jakimś wariancie współczesnego Freie Stadt Danzig? A gdyby zdominowana przez obywateli pochodzenia niemieckiego Rada Miasta ogłosiłaby autonomię Gdańska, jak na to zareagowałby polski rząd w Warszawie? Czy i tam, w stolicy Polski, pojawiliby się działacze polityczni skłonni do rozwiązań bardziej stanowczych? Czy ludność polska zaniepokojona obrotem zdarzeń wyszłaby na ulice, by przez wielką demonstrację wyrazić swoje przywiązanie do Polski? I czy z kolei ludność niemiecka odpowiedziałaby na to swoją, wielką demonstracją na placu Obrońców Poczty Polskiej, świętym dla Polaków miejscu, które przed wojną nosiło nazwę Heveliusplatz? A gdyby tę demonstrację zakłócili polscy narodowcy w czarnych koszulach i w trakcie zamieszek zostałby zraniony czy nawet zabity przypadkowy Niemiec? Co by wtedy zrobiło państwo niemieckie, gdyby w Internecie i na pierwszych stronach niemieckich gazet pojawiło się zdjęcie zakrwawionego Niemca jako bezbronnej ofiary narastającej polskiej przemocy? Co zrobiłoby państwo niemieckie, gdyby gdańscy Niemcy zwrócili się do niemieckiej macierzy z prośbą o ratunek, pomoc i wsparcie?

Że nic takiego nie dzieje się na Śląsku Opolskim, gdzie niemiecka ludność żyje w spokoju? Zgoda. Ale gdyby tam Niemców - oto kolejne fabularne wyzwanie dla literatury - żyło dzisiaj dwa i pół miliona? Więc autentycznie współczując w moich książkach Niemcom wypędzonym z Pomorza i Gdańska, ja, polski pisarz, autor Hanemanna i badacz literatury polskiej, drugą połową mojej duszy wcale im nie współczuję, przeciwnie: jako polski gdańszczanin cieszę się, że zostali z Gdańska wypędzeni? Bo gdyby sytuacja tak się rozwinęła, jak podpowiada literacka wersja „historii alternatywnej”, przecież uderzyłoby to także w moją rodzinę, którą w Gdańsku założyłem, a teraz mogę chodzić sobie spokojnie po gdańskich ulicach i nie muszę się martwić o bezpieczeństwo moich dzieci, wracających ze szkoły? Z mojej młodości nie pamiętam nawet jednego polskiego mieszkańca Gdańska, który by współczuł wypędzonym Niemcom. Wszyscy pamiętali, jak to w latach 30. 
młodzi mężczyźni z Hitlerjugend lubili z rozpędzonego tramwaju wyrzucać w biegu polskich uczniów wracających ze szkoły.

A Sudety? Jak rozwinęłaby się - oto kolejne wyzwanie dla literatury - sytuacja w Sudetach, gdyby mieszkający tam Niemcy nie zostali stamtąd wypędzeni dekretami Benesza i dzisiaj żyło ich tam trzy miliony? Czy po roku 1989, gdy pękła żelazna obręcz socjalizmu, znaleźliby się wśród nich tacy, którzy domagaliby się nie tylko autonomii dla Sudetów, ale i wystąpiliby zbrojnie w obronie niezależnej, niemieckiej Sudeckiej Republiki Ludowej, którą by proklamowali, zwracając się do państwa niemieckiego o pomoc i wsparcie? I czy w Sudetach pojawiliby się umundurowani mężczyźni bez znaków rozpoznawczych, przenikający przez granicę czesko-niemiecką z Zachodu, by wspierać cierpiących prześladowania, niemieckojęzycznych braci w ich bohaterskiej walce o powrót Kraju Sudeckiego do niemieckiej macierzy?

A polskie kresy? Literatura polska po roku 1989 krążyła już wokół tego rodzaju pytań, dając szereg „historii alternatywnych”, mniej lub bardziej niepokojących ${ }^{69}$. Czy gdyby Polska w 1989 roku miała granice z roku 1939, sprzed paktu Ribbentrop - Mołotow, sprzed Teheranu, Jałty i Poczdamu, tzn. obejmowałaby, tak jak przed wielkimi deportacjami, Litwę wileńską, Białoruś i Zachodnią Ukrainę, czy wtedy, gdy opadłaby żelazna obręcz komunizmu, antagonizmy narodowo-religijne, zamrożone - jak sugerowała Auderska w swojej powieści - przez Armię Czerwoną, wybuchłyby z dawną siłą i wschodnie terytoria postkomunistycznej Polski, sięgające po Dniestr, zmieniłyby się w żywą, krwawiącą ranę - drugą Jugosławię? A wtedy, czy taką krwawiącą Polskę przyjęłaby do swego grona Unia Europejska?

I czy gdyby tak rozwinęła się sytuacja na powojennym Wołyniu, na Polesiu, na zachodniej Ukrainie, w powojennym polskim Wilnie, w powojennym Gdańsku, w Szczecinie, na Pomorzu, na Śląsku, na Zaolziu, na słowacko-węgierskiej granicy, w czeskich Sudetach, w okolicach Królewca i Olsztyna, w Siedmiogrodzie, gdyby więc sytuacja tak się rozwinęła, jak podpowiada nam „historia alternatywna”, której kształty literatura przeczuwa - czy na początku XXI wieku powstałaby zjednoczona Europa w obecnym kształcie?

Więc - przed takim pytaniem stanęły po 1989 roku polskie powieści alternatywne - to Stalin - twardy wróg demokracji i dyktator - za przyzwoleniem zachodnich aliantów żelazną miotłą deportacji rozdzielając na

69 Np. Piotra Zychowicza Pakt Ribbentrop-Beck, Marcina Wolskiego Alterland, Ziemowita Szczerka Rzeczpospolita zwycięska. Alternatywna historia Polski, Macieja Parowskiego Burza. Ucieczka z Warszawy'40, Witolda Orłowskiego Stulecie chaosu. Alternatywne dzieje XX wieku. 
„terenach mieszanych" skłócone narody i religie, przygotował grunt pod powstanie demokratycznej Unii Europejskiej? Więc gdyby nie jego krwawe metody, Europa nie cieszyłaby się przez prawie 70 lat względnym spokojem i dobrobytem, tak jak cieszy się do dzisiaj, co w historii świata można uznać za nadzwyczajny dar losu?

A Ukraina? Czy gdyby w 1945 roku za przyzwoleniem Zachodu dokonano rozbioru Ukrainy, takiego samego jak rozbiór Polski, jakiego dokonano z przyzwoleniem Zachodu w 1945 roku, kiedy to chirurgicznym skalpelem wypędzeń odcięto od polskiej macierzy Kresy Wschodnie, oddając je w ręce czerwonej Rosji, czy gdyby w 1945 roku setki tysięcy Ukraińców ukraińskojęzycznych zostały przewiezione deportacyjnymi pociągami ze wschodniej Ukrainy do Ukrainy Zachodniej, gdyby chirurgicznym nożem deportacji oddzielono Ukrainę rosyjskojęzyczną od Ukrainy ukraińskojęzycznej, czy Ukraina krwawiłaby tak strasznie, jak krwawi dzisiaj, czy raczej żyłaby w spokoju? I czy nie należałoby tego samego zrobić z Estonią i Litwą, oddzielając nożem deportacji ludność rosyjską od ludności nierosyjskojęzycznej w imię pokoju, dobrobytu i sytości całej Europy a może i świata?

Zatem niech będą błogosławione wypędzenia, dzięki którym Europa jest dzisiaj taka jaka jest, tzn. mimo licznych wad zupełnie nie najgorsza? I cierpienie wypędzonych, ów główny temat narracji deportacyjnych, to nic innego, jak tylko ból fantomowy, odczuwany po każdej bolesnej, lecz koniecznej operacji chirurgicznej, dzięki której powracamy do zdrowia? Za łatwy to byłby wniosek, bo tego bólu nie da się niczym wymazać. Niczego tu nie zmieni żadna historyczna buchalteria zmiennych perspektyw narracyjnych. Bezbrzeżne morze cierpień deportowanych z jednej strony, a z drugiej bezbrzeżne morze korzyści, jakie deportacje zapewniły powojennej Europie i powojennemu światu - jaką miarą mierzyć ten bilans bez ideologicznego sentymentalizmu, politycznego zacietrzewienia czy nostalgicznych marzeń o rewanźu, ale i bez historiozoficznego cynizmu, który pcha w stronę obojętności? Prawdziwym wyzwaniem aksjologicznym dla literatury jest mrok tych pytań.

Bo przecież my wszyscy, Polacy i Niemcy - chcąc, czy nie chcąc - w mniejszym lub większym stopniu jesteśmy beneficjentami wypędzeń, żyjąc w dzi siejszej - zupełnie niezłej, choć chwiejnej i niepewnej - Europie, która bez deportacji prawdopodobnie by nie powstała? Fundamentem naszego dobrostanu i dobrobytu jest zatem zło, które się wówczas, w latach 1939-1950, dokonało, o czym zwykle nie chcemy nawet słyszeć? Jak literatura mogłaby zdefiniować to zło? I w jaką to formułę filozoficzną je ująć? Aksjologia „historii alternatywnej" prowadzi nas bowiem do filozoficznych pytań o tajemnicę 
„dobrego zła”, o którego istnieniu był przekonany Goethe, kiedy w usta swojego Mefistofelesa w Fauście wkładał jedno z najbardziej niepokojących zdań ludzkiego języka: „Ja jestem zło, co dobro czyni", którego nieprzenikniony sens pozostaje przed nami wciąż zakryty.

\section{Abstract}

\section{Stefan Chwin}

UNIVERSITY OF GDANSK

The Great Central-European Deportations of 1939-1950 from an Axiological Perspective: A Challenge for Literature

This article focuses on the basic question of what axiological perspectives are found in Polish and German deportation narratives from the second half of the twentieth century. Chwin also asks what kinds of axiological challenges mass deportation and expulsion has posed (and still poses) for literature. Numerous writers and chroniclers witnesses as well as participants - have tackled the issue, and their writings continue to be published in Poland and in Germany. Chwin presents a preliminary typology of axiological perspectives that give direction to narratives of deportation in Polish and German literature of the second half of the twentieth century and the beginning of the twenty-first. He isolates the following basic perspectives: 1. the Nemmersdorf axiology 2. the axiology of biographical recapitulation, 3. the axiology of deportation and of the 'ideological fatherland', 4. the axiology of historical recapitulation of deportation and 5. the axiology of'alternative history'. The article passes over the axiology of reconciliation in Polish literature after 1989 - a topic that deserves a separate study.

\section{Keywords}

expulsion, deportation, resettlement, axiology in literature, history of the twentieth century 